\title{
From Past to Present: The Journey of Female Doctors in Medicine and Otorhinolaryngology in Turkey
}

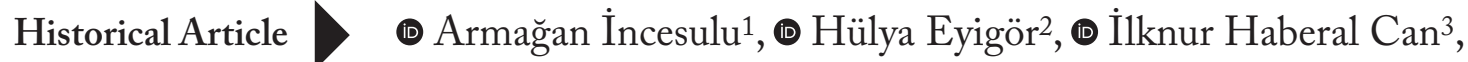 \\ (1) Sema Başak ${ }^{4}$
}

\author{
${ }^{1}$ Department of Otorhinolaryngology-Head and Neck Surgery, Eskişehir Osmangazi University, School of \\ Medicine, Eskişehir, Turkey \\ ${ }^{2}$ Department of Otorhinolaryngology-Head and Neck Surgery, University of Health Sciences Turkey, \\ Antalya Health Practice and Research Center, Antalya, Turkey \\ ${ }^{3}$ Department of Otorhinolaryngology and Head and Neck Surgery, Yozgat Bozok University, School of \\ Medicine, Yozgat, Turkey \\ ${ }^{4}$ Department of Otorhinolaryngology-Head and Neck Surgery, Adnan Menderes University, School of \\ Medicine, Aydın, Turkey
}

\section{Introduction}

Patience, diligence, being able to adapt to changing conditions, having good communication skills, being open to innovations, and coping with crises are the almost-innate skills of women. The same features are predictive for success in the field of medicine. However, throughout history, women have been kept away from the field of medicine by claiming that they do not possess the aforementioned features. Further, their prescribed roles were limited to midwives and assistants to male doctors. Although all these, female physicians/surgeons, who have made their mark since ancient times, have existed in Turkey as well as worldwide.

\section{Ancient Times}

The lands of the Republic of Turkey have been the cradle of civilizations for centuries, which pioneered the birth of philosophy, art, architecture, and medicine. In ancient times (10,000-5,500 B.C.), people believed that diseases were created by evil spirits. Therefore, clerics or shamans conducted the treatments. Although magic and herbs were often used for treatment, surgical procedures such as trepanation (opening a hole in the skull), possibly aimed at removing evil spirits from the body, were also used to cure diseases. The evidence obtained during excavations has not revealed how and by whom these operations were conducted. However, it is not difficult to guess that these were most likely done by male clerics.

Among Hittites, who ruled in Anatolia from 2,100-1,190 B.C., scribes documented and archived the events of their civilization on clay tablets very 
carefully. These documents showed that women also affected the field of medicine. The clay tablets described female doctors with the names Makiya and Mammitum-um-mi. For Hittites, medical treatment was based on herbs, besides fortune-telling and magic. According to some authors, the women in medicine only took part in magic rituals (1). On one of the clay tablets, it was reported that a female doctor/ healer probably treated a male with sexual dysfunction through religious ritual prayers (2). Additionally, women were thought to be superior in obstetrics and gynecology. They helped during births as midwives and cast spells to facilitate the birth process. Spells and prayers made for the baby to lead a healthy and good life after birth were also made by midwives. According to the inscriptions, the Hittites also documented abnormal births and interpreted abnormal findings as harbingers of future events. One tablet said: "in the absence of the right ear; the enemy will claim the King's land and in the absence of the left ear; the King will claim his enemy's land." That is interesting, as we know that microtia is more common in the right ear and in boys.

The records of the Eastern Roman period (395-1071 A.D.) stated that despite mainly male doctors working in hospitals established in Istanbul, a female doctor and a female surgeon were also present. Interestingly, 12 assistants and eight support staff were employed to assist male doctors, whereas this number was four assistants and two support staff for female doctors. This finding indicated discrimination against female doctors at that time, which continues today (2).

It is impossible to find any documents proving the practice of female doctors in Anatolia from the $11^{\text {th }}$ to the $17^{\text {th }}$ century. However, Al-Zahrawi, who worked in Andalusia in the $10^{\text {th }}$ and $11^{\text {th }}$ centuries and was one of the pioneers of modern surgery, stated that especially gynecological procedures in female patients could not be performed by male doctors and hence needed to be performed by a woman or midwife, who was instructed by a male doctor. Based on this information, it can be suggested that women were only trained based on practice and they were primarily expected to perform gynecological/obstetrical procedures.

\section{Ottoman Period}

The records show that after the death of Deniz bin Gazi, the famous inguinal hernia surgeon in the $17^{\text {th }}$ century in the Ottoman Empire, his wife Saliha bint-i Küpeli performed hernia surgery. Saliha bint-i Küpeli continued the surgical procedure learned from her husband and could successfully treated not only patients from Istanbul but patients from all regions dominated by the Ottoman Empire such as Rumelia, Chios, Morea, Erzurum, and İnegöl (3). The records also show that janissaries Mehmed Beşe and Ali Beşe were among her patients. Female surgeon Küpeli Saliha Hatun had to obtain a consent form from all her patients in the Religious Court before performing the procedure like other physicians and surgeons who served in the Ottoman Empire, the consent deed was a document that would protect a physician performing the treatment or procedure from relatives filing blood feuds and blood money lawsuits in the case of any complication. The fee to be received by the surgeon was also recorded. The examination of the Ottoman archives showed clear differences between the fees charged by the same physician for similar procedures. This depended on the difficulty of the procedure or the patient's financial status. While Saliha bint-i Küpeli received between 300 and 3,000 coins for her surgical procedures, Deniz bin Gazi, from whom she learned the profession, received between 400 and 1,000 coins for hernia surgeries. This finding indicated that a surgeon who successfully performed the surgery was valued, regardless of whether it was a woman or a man (4).

Zeynep bint-i Mustafa, who could be considered a contemporary of Saliha bint-i Küpeli, removed a mass in a man's neck in the village Köyviran of the small town Şuhud in 1691 (5).

Apart from the aforementioned rare examples, the woman's place in social life in the Ottoman Empire was limited. No women could work, show herself in public, or own certain rights due to religious and traditional reasons. However, women's movements, which were initiated by educated women in the $19^{\text {th }}$ century in cities such as Istanbul, Thessaloniki, and İzmir, gained momentum during the Tanzimat period. Although women gained certain rights with these efforts, their applications made for admission to medical faculties were evaluated and rejected by the State Council on their decision on May 23 $3^{\text {rd }}, 1898$ claiming that women could not work as doctors due to the perception that their chastity would be impaired, they would not be able to examine male patients, they would not be eligible to participate in anatomy dissections, and they could not continue their profession after getting married and having children (5).

Women, who wanted to become doctors during this period, received medical education in the United States of America (Chicago University of Illinois), Switzerland (Geneva Medical School), Germany (Würzburg University Faculty of Medicine), and England (London Medical School), then returned to Turkey. However, according to the Ottoman rules, these women could not practice on their own. One of these students, Zaruhi Kavalciyan, an Ottoman citizen, returned to her country in 1903 following her medical education in the United States and started working next to her father Dr. Serope Kavalciyan, who was also a doctor. Dr. Kavalciyan took over her father's patients after he suffered from a stroke, and attended educational activities (6).

The first Turkish female doctor, Hatice Safiye Ali, shared the same fate despite having excellent education. Safiye Ali, who lost her father at a young age and grew up in the mansion of her grandfather Hacı Emin Pasha, who was the shaykh 
al-Islam of Mecca, did not give up. She went to Germany with the support and scholarship of the board of education. She was sad that she could not study in her own country, which also had a medical school. However, she stated in her correspondence with Mr. Ali Haydar, Official of the Ottoman Student Delegation, that she was aware she represented Turkish women in Germany and would strive to glorify Turkish women. With this motivation, Safiye Ali graduated from the Faculty of Medicine, Würzburg University, in 1921 and returned to her country. However, Dr. Safiye Ali was not satisfied with her education and returned to Germany six weeks later to specialize in women's and pediatric diseases. Meanwhile, the Republic was not announced yet, but the Grand National Assembly Government of Turkey had been founded. After her application was evaluated, she was granted permission in 1923 to become the first female doctor in Turkey. The permission was named "Mr. Safiye Ali," which perfectly summarized the situation (5).

After that, Safiye Ali opened a clinic in Istanbul but again faced various difficulties. First, patients did not trust a female doctor and did not want to go to her, after which they proposed only to pay half of the examination fee. She was also subjected to negative propaganda from her male colleagues. Safiye Ali continued her work and treated patients free of charge in the Hilal-i Ahmer Ladies' Center Little Children Practice, the Mothers Union, and the Turkish Women's Association Children's Practice. Also, she educated women in the Himaye-i Etfal Society Milk Drop Establishment, where she worked and later managed, in subjects such as the importance of breast milk, baby care, nutrition, and health rules.

Besides being the first woman to teach in a medical school in Turkey (she became the first female lecturer to teach at the first female medical school established within the American College), she was the first Turkish female doctor attending international congresses. The first congress she attended was the International Women Doctors Congress in London in 1924. She was one of 300 female doctors attending from 300 countries. In the same year, she attended a congress in Vienna, and in 1928, she attended two more international congresses in Bologna. In these international congresses, she mentioned the reforms and health services provided for women and children by the newly established republic and its founder Gazi Mustafa Kemal Atatürk (7).

\section{Period of Republic of Turkey}

During the years when Safiye Ali started to practice as a doctor, six female students admitted to the medical faculty for the first time, thanks to the efforts of Dr. Besim Ömer Pasha and Dr. Adnan Adivar, graduated in 1928 and started to practice in a more relaxed atmosphere in the young Republic founded by Mustafa Kemal Atatürk. One of these doctors Ifffet Naim (Onur) (1906-1995) practiced obstetrics and gynecology received training from Dr. Akif
Şakir at Turkey's first Orthopedic Surgery and Pediatric Surgery Clinic, and continued her career as a surgeon. She is one of the founding members of the Turkish Orthopedics and the Traumatology Surgery Association. Fatma Müfide Kazım (Küley) (1899-1985) became an expert in Internal Medicine and Gastroenterology; Hamdiye Abdürrahim (Rauf) Maral (1895-1975) in Dermatology, Physical Therapy, and Radiotherapy; Sabiha Süleyman (Sayın) (1903-1984) in Pediatrics; Suat Rasim (Giz) (1903-1980) in Surgery, especially Thoracic Surgery; and Fitnat Celal (Taygun) (1898-1985) in Surgery. Mrs. Sabiha Süleyman, one of these pioneer women, received a salaried staff position for the first time as a female doctor in 1929 (6). These pioneering women continued their struggle so that other women could get a medical education and set an example for future generations. Meanwhile, thanks to the implemented revolutions, the women in Turkey gained more rights.

The first female Ear-Nose-Throat (ENT) specialist in Turkey was Dr. Hatice Bodur. Dr. Bodur was initially unaccepted by the medical school and started the Chemistry Department of Istanbul University Science Faculty. Dr. Bodur graduated as valedictorian, worked as a chemist for the next nine years and applied to medical school in 1931. After graduation, she worked as an honorary assistant at the Istanbul University Otorhinolaryngology Clinic between 1940 and 1943, besides her biochemistry education and received the title of otorhinolaryngologist after successfully passing the exam in 1943 (Figure 1) (8).

Dr. Emine Bağdad was the second female otolaryngologist in the young Republic of Turkey, although it was unknown

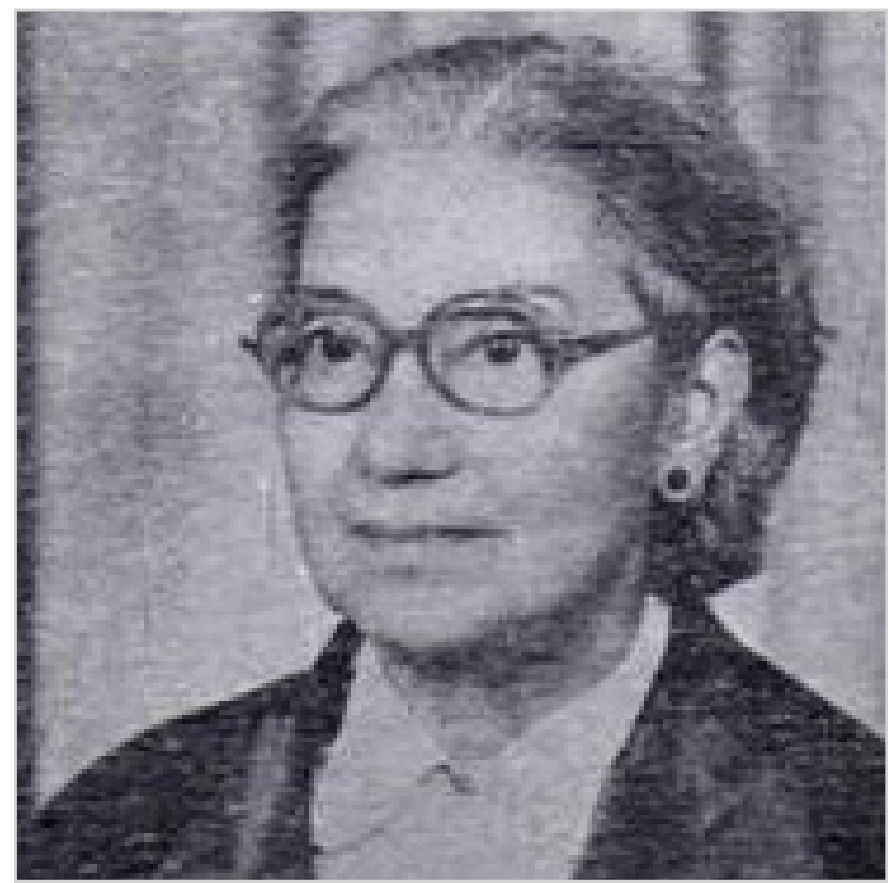

Figure 1. Hatice Bodur. The first female Ear-Nose-Throat (ENT) specialist in Turkey 
when she has obtained her title as a medical doctor and when she received the degree of otorhinolaryngologist. We only have her prescription dated 1952 and her business card (Figures 2 and 3).

Prof. Dr. Nermin Başerer, who is the first female academic in Otorhinolaryngology, was born in 1943. In 1966, she graduated from medical school, which she attended at the insistence of her father, then started her residency in the Otorhinolaryngology Clinic under the guidance of her Physiology instructor. Prof. Dr. Başerer, who decided to leave the department of otorhinolaryngology after only a few months, was motivated by the words of Prof. Dr.

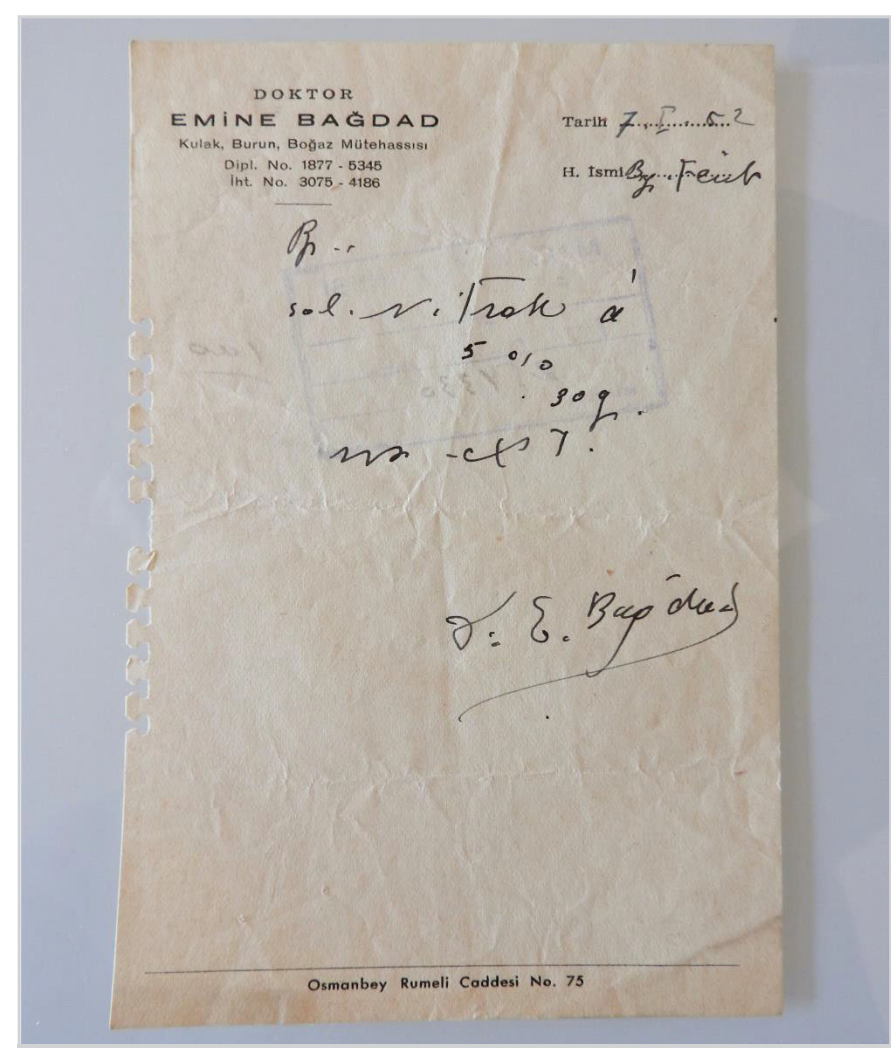

Figure 2. Dr. Bağdad's prescription dated 1952

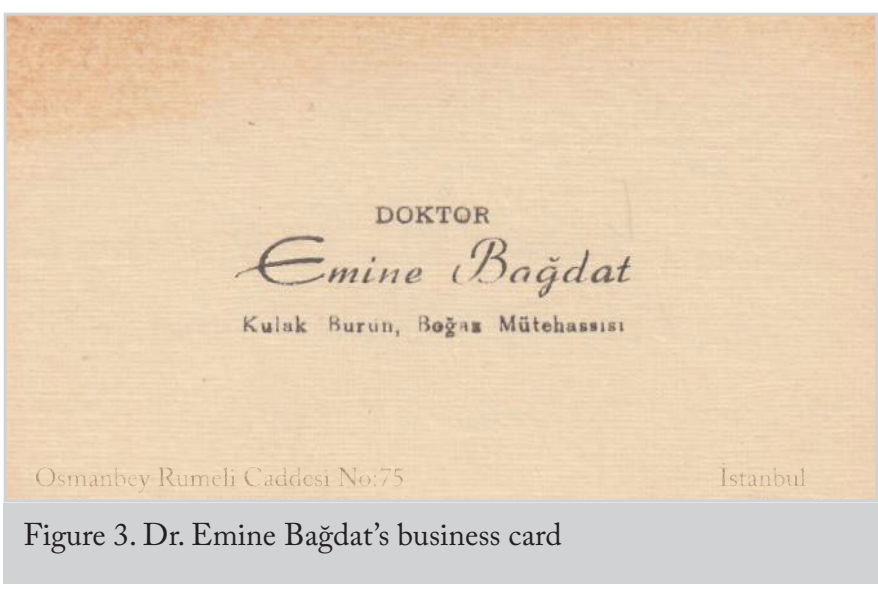

Behbut Cevanşir who was head of the department: “... Your report card is full of success, if you work hard and show persistence you will become the first female academician in the field of otorhinolaryngology in Turkey." After this, she successfully finished her training (Figure 4). During 1973-1975, she worked as a foreign chief assistant in Lyon, France, performed successful surgeries, and investigated the effects of psychoactive drugs on the balance system. Prof. Dr. Başerer, who stated with pride that her teacher in France introduced her everywhere as "The daughter of Mustafa Kemal," successfully represented Turkey with her surgeries and work as a woman coming from Atatürk's Turkey.

Prof. Dr. Nermin Başerer, who became an assistant professor in 1976, successfully served as the first female head of department in Turkey between 1988 and 1991 (Figure 5). Prof. Başerer, who served as the first woman president of the Turkish Otorhinolaryngology Head and Neck Surgery Association founded in 1932, between 2006 and 2008, said the following about her duty: "The fact that I became the first female president of the association was a duty given to me and I accepted that duty. This was not a vision. However, it was gratifying for me to show the whole world, as a Turkish woman, that the medicine in Turkey and that an academician in Turkey can reach this point in a world that is dominated by man. This is a heavy duty but also peaceful." Prof. Dr. Nermin Başerer, who served the field of otorhinolaryngology for 44 years, worked extensively on head and neck cancers and aural atresia and applied the "Başerer shunt" method. She successfully published many scientific articles and books, achieved immense academic success and practiced her profession until she passed away in 2020 (9).

The number of female otorhinolaryngology specialists and academicians, who are on the path opened by Professor Başerer, increases with each passing year; however, it is still relatively low. Although the second female president

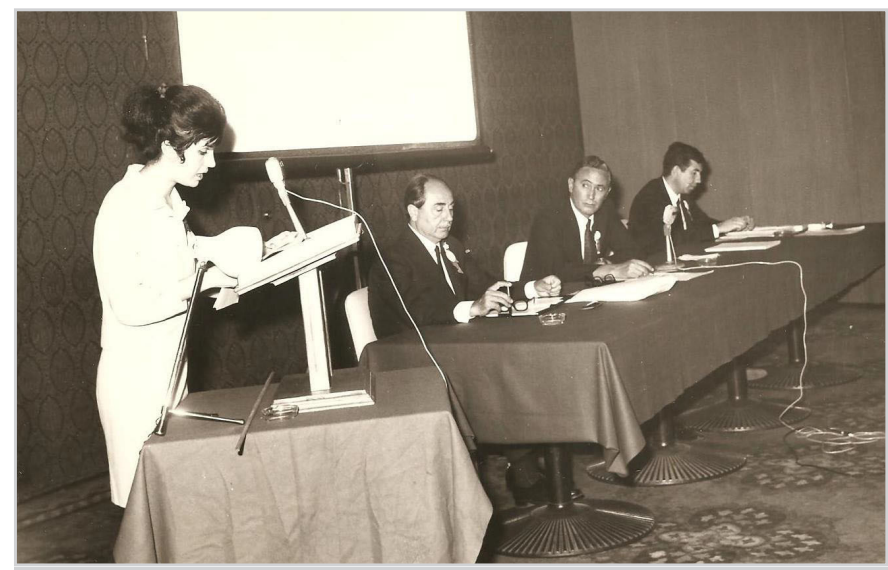

Figure 4. Prof. Dr. Nermin Başerer. She was giving a lecture in National ENT Congress in 1969 in İstanbul. It was the first congress she attended. 


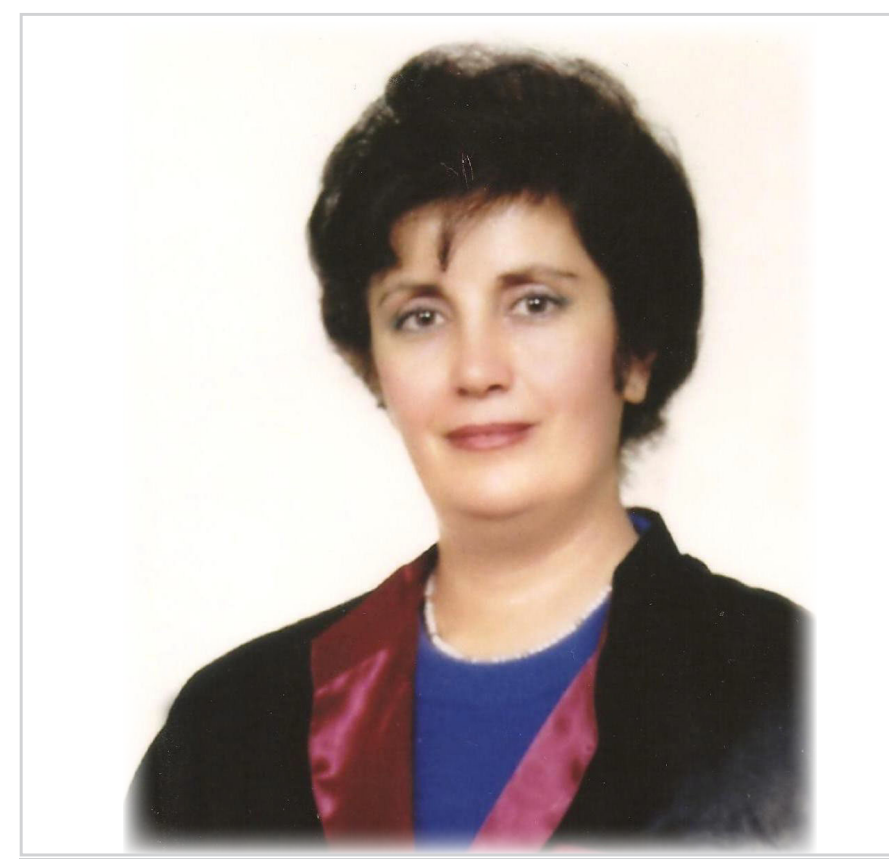

Figure 5. Prof. Dr. Nermin Başerer. the first female head of Otorhinolaryngology department in Turkey between 1988 and 1991

was not nominated in the history of the Turkish Society of Otorhinolaryngology Head and Neck Surgery (TSOHNS), sub-association presidencies were successfully carried out by Prof. Dr Nesil Keleş, Prof. Dr Sema Başak, and Prof. Dr Ülkü Tuncer. Moreover, female instructors contributed to our field by serving in several committees of the TSO-HNS.

Prof. Dr. Emine Elif Altuntaş, Prof. Dr. Sema Başak, Prof. Dr. Aslı Şahin Yılmaz, Prof. Dr. Sema Zer Toros, Prof. Dr. Berna Uslu Coşkun, Prof. Dr. Ceren Günel, Prof. Dr. Fatma Tülin Kayhan, Prof. Dr. Ülkü Tuncer, and Prof. Dr. Serap Köybaşı in Qualification Board of TSO- HNS Higher Education Commission; Prof. Dr. Güleser Saylam, Prof. Dr. Emel Çadallı Tatar, Prof. Dr. Müge Özcan, Prof. Dr. Adin Selçuk in Qualification Board of TSO-HNS Examination Board; Prof. Dr. Zeynep Alkan and Prof. Dr. Tuba Bayındır in Qualification Board of TSO-HNS Education Commission; Prof. Dr. Armağan İncesulu and Prof. Dr. Nesil Keleş in Qualification Board of TSO-HNS Executive Board enthusiastically acted in their term.

\section{The Journey of Female Doctors in the World}

While these developments occurred in Anatolia, the journey of female physicians in the world was not easy. The acceptance of female students by medical schools in England started only at the end of the $19^{\text {th }}$ century. An interesting example is that of Dr. James (Miranda) Barry. Dr. Barry finished her education in 1812 and worked as a doctor for many years. She even attained the honor in the British army as the Inspector General of Hospitals. Dr. Barry was a woman who was understood only after her death in 1865 (10).
The first woman to be accepted by the "male" medical school in the United States of America was Dr. Elizabeth Blackwell (1821-1910). Blackwell, who graduated in 1949, was accepted by the school only with the approval of the male students. Dr. Blackwell, who was born in England and had to move to the USA for family reasons, was previously rejected by 20 medical schools. Returning to England after her graduation, Dr. Blackwell was the first female member accepted by the General Medical Council in 1858, which allowed doctors to work in England. The fact that it was difficult for women to be accepted at medical faculties has led to the necessity of opening "female" medical schools. The New England Female Medical College was opened in 1848, the Woman's Medical College of Pennsylvania was opened in 1850 in the USA, and the London School of Women was opened in England in $1874(10,11)$. The Constantinople Women's College, which was opened in Turkey for the same reason in 1920 within the İstanbul American Girls' College, was closed due to the Unification of Education Law of March $3^{\text {rd }}, 1924$, which prohibited foreigners from establishing and employing higher education institutions (5).

Dolors Aleu i Riera was the first female doctor to receive her doctor's license in Spain in 1882, three years after graduating. The first female doctor in Germany was Dorothea Christiane Erxleben who got her diploma in 1754. Ogino Ginko gained the right to practice as a doctor in 1885 in Japan. The first female doctor in Italy was Dorotea Bucca, who had a chair at Bologna University in 1390 (12).

Margaret F. Butler was the first female doctor in the United States to become specialized in the field of Otorhinolaryngology; she became the department head and a professor in 1906. Besides the surgeries she performed, she also designed different instruments. The first female consultant in the field of Otorhinolaryngology in England was Mrs. Esme Hadfield. The Polish female neurologist Lucia Frey was not an otorhinolaryngologist, but she defined Frey's syndrome in 1923, which was an important breakthrough in related field (10).

\section{Current Situation of Female Otolaryngologists}

The journey of women in medicine in Turkey and across the world has not been easy. Although women's movements, which started in the 1800s, gained momentum, the journey was not always easy, especially in surgical branches and otorhinolaryngology. The first study in this regard published in 2019 reported that $53.2 \%$ of female ENT specialists were exposed to discrimination during their specialty training. The decision-making positions in universities and professional associations are still "male-dominated." Despite no significant difference in the remuneration of female and male otorhinolaryngologists in Turkey, the salary of women is less than that of men in some countries, including developed ones (13). Among the academic journals in the field of ENT 
in Turkey, only the journal Ear Nose Throat Applications have a female editor (Prof. Dr. Fatma Tülin Kayhan). Also, none of the world's leading otorhinolaryngology journals employ female editors as the Editor-in-Chief (14).

\section{Conclusion}

The admission of women to medical schools or to the surgical field is no longer a fundamental problem, but this area still has some challenges. Sex discrimination still exists when trying to find a place in decision-making positions, in work environments and professional organizations, as well as in academic and senior leadership positions. Steps to be taken in this regard may help reveal the existing potential in women.

\section{Authors Contributions}

Conception: S.A.İ., Design: S.A.İ., Supervision: S.B., Data Collection and/or Processing: H.E., İ.H.C., Literature Review: S.A.İ., İ.H.C., Writing: S.A.İ., Critical Review: İ.H.C.

Conflict of Interest: There is no conflict of interest

Peer-review: Externally peer-reviewed.

Financial Disclosure: This research received no specific grant from any funding agency, commercial or not-forprofit sectors.

\section{References}

1. Ceran B. Medicine in Ancient Egypt and Ancient Anatolian Civilizations. Selçuk University Institute of Social Sciences Primary Education Division Social Studies Education Division. Master Thesis. 2008, Konya (Antik Misır ve Eski Anadolu Uygarlıklarında Tıp. T.C. Selçuk Üniversitesi Sosyal Bilimler Enstitüsü İlköğretim Ana Bilim Dalı Sosyal Bilgiler Öğretmenliği Bilim Dalı. 2008, Konya) [Crossref]

2. Yalçın BM, Ünal M, Pirdal H, Selçuk Y. [The history of medicine in Anatolia - 1st Part]. Türk Aile Hek Derg 2016; 20: 33-44. [Crossref]
3. Demirsoy N, Sayligil O, Topal M, Ozden H. A female surgeon in the 17th century: Küpeli Saliha Hatun and an evaluation of consent forms related to her surgeries. Konuralp Med J 2019;11: 468-74. [Crossref]

4. Akkaya M. [A surgeon family in Ottoman Üsküdar: master surgeon Deniz, his wife-surgeon Küpeli Saliha and his sonsurgeon Mehmed Çelebi]. History Stud Int J History 2014; 6: 1-10. [Crossref]

5. Yıldırım N. Dünyada ve Türkiye'de ilk kadın hekimler: Kadınların hekim olma mücadelesi Toplumsal Tarih 2006; 147: 50-7. [Crossref]

6. Atıcı E, Erer S. Türk kadınlarının tıp eğitimine başlama süreci ve İstanbul Darulfününü Tıp Fakültesi'nden mezun olan ilk kadın hekimler Uludağ Üniversitesi Tıp Fakültesi Dergisi 2009; 35: 10711. (Article in Turkish) [Crossref]

7. Konya D. [Turkey's First Woman Doctor: Safiye Ali and Activities]. Journal of Social Sciences and Humanities Researches 2018; 19: 35-54. (Article in Turkish). [Crossref]

8. Tanyeri Y. Once upon a time. Memories from the history of Otorhinolaryngology. İstanbul: Argos Cotex, 2007. [Crossref]

9. Başaran B, Keleş Türel N. In Memoriam: Professor Nermin Başerer. Turk Arch Otorhinolaryngol 2020; 58: 71-4. [Crossref]

10. Konstantinidou S, Adams M. Women in otorhinolaryngology: a historical perspective.J Laryngol Otol 2018; 132: 670-2. [Crossref]

11. Jefferson L, Bloor K, Maynard A. Women in medicine: historical perspectives and recent trends. Br Med Bull. 2015; 114: 5-15. [Crossref]

12. List of first female physicians by country [Internet]. Wikipedia [Cited 2020 October 15]. Available at: https://en.wikipedia.org/ wiki/List_of_first_female_physicians_by_country [Crossref]

13. Eyigör H, Can İH, İncesulu A, Şenol Y Women in otolaryngology in Turkey: Insight of gender equality, career development and work-life balance. Am J Otolaryngol 2020; 41: 102305. [Crossref]

14. Litvack JR, Wick EH, Whipple ME. Trends in female leadership at high-profile otolaryngology journals, 1997-2017. Laryngoscope 2019; 129: 2031-5. [Crossref] 